\title{
UPAYA LEMBAGA RIFKA ANNISA WOMEN'S CRISIS CENTER DALAM MENANGANI KORBAN KEKERASAN TERHADAP PEREMPUAN
}

\author{
Oleh: \\ Intan Kusumawati \\ Universitas Cokroaminoto Yogyakarta
}

\begin{abstract}
Abstrak
Penelitian ini bertujuan untuk mengetahui upaya dan hambatan-hambatan Lembaga Rifka Annisa Women's Crisis Center dalam menangani korban kekerasan terhadap perempuan. Metode pengumpulan data yaitu wawancara dan dokumentasi. Teknik yang digunakan dalam menentukan subjek penelitian adalah purposive. Subjek penelitian ini adalah Ketua Lembaga Rifka Annisa Women's Crisis Center, dua staf divisi pendampingan, satu staf divisi pendidikan dan pelatihan, satu staf divisi pendampingan, dan satu staf divisi hubungan masyarakat. Untuk memeriksa keabsahan data digunakan teknik cross check, dengan membandingkan atau mengecek data hasil wawancara dengan dokumentasi. Teknik analisis data menggunakan teknik analisis induktif. Adapun langkah-langkahnya, yaitu reduksi data, unitisasi dan kategorisasi, display data dan terakhir pengambilan kesimpulan.

Hasil penelitian ini menunjukkan, bahwa Lembaga Rifka Annisa Women's Crisis Center dalam upaya menangani korban kekerasan terhadap perempuan melakukan 2 upaya, yang pertama adalah upaya preventif yaitu: (1) Diskusi-diskusi tentang KTP. (2) Traning penanganan perempuan korban kekerasan bagi TP-PKK, (3) Kumpulan catatan/position paper, (4) Pengembangan konsep RPK, (5) Pandangan mengenai persepsi gender/ Survey persepsi gender pembuat kebijakan, (6) Pemantauan tinadakan litigatif yang dijalani oleh perempuan korban kekerasan dan perumusan kebijakan praktek aparat hukum/policy brief, (7) Program jaringan, (8) Penertiban, (9) Kolom tetap di majalah Manggala dan Harian Kompas, (10) Program radio dengan talkshow "Swaranisa", (11) Pemutaran dan diskusi film, (12) Pengolaan perpustakaan, dan (13) Program pantau keluarga. Upaya yang kedua adalah upaya represif yaitu: (1) Pendampingan/konseling, (2) Pendampingan hukum/Litigasi, (3) Mengelola rumah singgah sementara/shelter, (4) Pendampingan medis, (5) Kunjungan ke rumah korban/ home visit dan monitoring. Hambatan-hambatan yang dialami Lembaga Rifka Annisa Women's Crisis Center dalam upaya menangani korban kekerasan terhadap perempuan adalah respon korban diam, menyembunyikan informasi, berbohong tentang sesuatu hal, padahal hal tersebut penting untuk diinformasikan, korban tipe orang yang penakut dan ragu, korban suka bertahan pada opininya, korban tipe orang yang penakut dan ragu, korban suka bertahan pada opininya, korban menuntut hak-haknya untuk ke pengadilan, sementara bukti-bukti dan saksi belum mencukupi.
\end{abstract}

Kata Kunci: Lembaga Rifka Annisa Women’s Crisis Center, Korban Kekerasan, Perempuan 


\section{Pendahuluan:}

Kekerasan terhadap perempuan adalah bentuk pelanggaran hak asasi manusia dalam masyarakat. Kekerasan pada perempuan pada perempuan juga merupakan masalah masalah yang serius dalam bidang kesehatan karena melemah energi perempuan, mengikis kesehatan fisik dan harga dirinya. Di samping menyebabkan luka-luka kekerasan juga memperbesar resiko jangka panjang terhadap masalah kesehatan lainnya, termasuk penyakit kronis, catat fisik, penyalahgunaan obat dan alkohol, serta depresi. Perempuan dengan riwayat penganiayaan fisik dan seksual juga meningkatkan resikonya untuk mengalami kehamilan yang tidak yang tidak diinginkan, penyakit menular seksual (PMS) dan pasca kehamilan yang kurang baik. Jenis kekerasan pada perempuan yang terjadi di masyarakat berupa Kekerasan Terhadap Istri (KTI), Kekerasan dalam pacaran (KDP), Pelecehan seksual, Perkosaan dan Kekerasan dalam keluarga (KDK). Dalam banyak kasus, pada umumnya para pelakunya terkena ancaman hukuman berdasarkan pasal-pasal 351 KUHP (penganiayaan), Pasal 352 KUHP (penganiayaan yang ringan), pasal 353 KUHP (penganiayaan yang direncanakan), Pasal 354 KUHP (penganiayaan berat), Pasal 355 KUHP (penganiayaan berat yang direncanakan).

Ketentuan-ketentuan di atas meskipun memang tidak secara eksplisit mengatur tentang kekerasan terhadap perempuan tapi setidaknya dapat digunakan untuk mengadukan perkaranya kepada polisi dan bahkan KUHP memberikan hukuman lebih berat jika penganiayaan itu dilakukan terhadap istri atau suami. Pemberatan hukuman ini juga ditujukan kepada suami atau istri yang melakukan penganiayaan. Banyak kasus kekerasan terhadap perempuan yang terjadi saat ini. Seperti seorang ibu rumah tangga yang dipaksa suaminya untuk melakukan hubungan intim, bahkan istri sedang menstruasi dan suami sering berbicara kasar, dan merendahkan istri (Kompas, Senin, 14 Juli 2003, hal 45). Ada lagi seorang istri yang dipukuli suaminya sehingga jatuh mengenai aspal di jalan Sisingamangaraja Yogykarta, yang berakibat korban mengalami luka memar bagian wajah dan tubuh kemudian dilarikan ke RS PKU Muhammadiyah Yogyakarta (Bernas, 15 Januari 2003, hal 16). Itu tadi contoh kasus Kekerasan Terhadap Istri.

Kasus kekerasan dalam pacaran yakni seorang gadis remaja yang dipaksa oleh pacarnya untuk melakukan hubungan layaknya suami istri untuk menyatakan cintanya sampai akhirnya gadis itu hamil. Pemuda tersebut mengancam agar gadis tersebut tidak menceritakan kepada siapapun termasuk keluarganya (Kompas, Senin, 14 Juli 2003, hal 45). Bahkan di Yogyakarta 
yang terkenal dengan kota pelajarnya, seorang gadis dicabuli oleh seorang pemuda IS (27th) warga Tegalrejo di hotel di Bilangan. Dengan cara mengajak gadis tadi untuk minum yang sudah diberi minuman keras, setelah pusing diajak ke hotel, ditelanjangi sampai setengah bugil dan diraba-raba bagian tubuhnya (Kedaulatan rakyat, 6 Januari 2003, hal 9). Seorang gadis A (20th) dicabuli oleh seorang pemuda M (37th) warga Baki Sukoharjo dalam sebuah bus Yogya-Solo dengan cara pura-pura tidur disampingnya dan tangannya diletakkan di paha korban akhirnya meraba-raba bagian tubuh korban (Kedaulatan Rakyat, 13 Februari 2003, hal 6).

Kasus perkosaan yang terjadi di sebuah rumah di Ngestiharjo Kasihan Bantul, oleh seorang ayah tiri Ds (45th) memaksa anak tirinya untuk melampiaskan nafsunya dengan memperkosa anak tirinya. Setelah berhasil menyetubuhi anak tirinya hingga hamil 5 bulan dan mengancam untuk tidak menceritakan kepada siapapun (Kedaulatan Rakyat, 26 Januari 2003, hal 6). Seorang anak perempuan diperkosa oleh Kursa (45th) masih tetangga di Pundong Bantul dengan diiming-imingi buah talok di sebuah bangunan rumah yang belum jadi (Kedaulatan Rakyat, 6 Januari 2003, hal 6). Berdasarkan berita-berita di media massa tadi, dapat dilihat banyak kasus kekerasan terhadap perempuan yang terjadi. Banyaknya kasus tindak kekerasan terhadap perempuan merujuk pada beragam tindak pemaksaan secara seksual, psikologis dan fisik terhadap perempuan.Tindak kekerasan terhadap perempuan (KTP) semakin marak, dan bukan semata-mata karena media massa yang semakin transparan dalam mengungkapkan persoalan tersebut, sehingga masalah ini seakan semakin banyak angkanya. Perlu adanya penanganan dan mencari akar permasalahan setelah mengetahui apa saja penyebabnya yang menjadikan terjadinya KTP tersebut. Budaya patriarkhi dan diperkuat rendahnya pemahaman kesetaraan gender menjadi kunci yang mendasari hal tersebut.

Tindakan kekerasan terhadap perempuan (KTP) sekarang ini menjadi persoalan bagi masyarakat. Upaya-upaya yang telah banyak dilakukan oleh masyarakat, terutama oleh pihakpihak yang berwenang, misalnya: Lembaga Swadaya Masyarakat (LSM) yang peduli akan masalah perempuan dengan mendirikan Women's Crisis Center (WCC), pihak kepolisian mendirikan Ruang Pemeriksaan Khusus (RPK) dan pihak rumah sakit swasta mendirikan Ruang Pemeriksaan Khusus (RPK) dan pihak rumah sakit swasta mendirikan Unit Pelayanan Perempuan (UPP). Orang pun mulai menerima lembaga “Women's Crisis Center" sebagai tempat untuk berlindung. Sudah banyak LSM yang berupaya membantu korban KTP, salah 
satunya adalah Lembaga Rifka Annisa Women's Crisis Center. Lembaga Rifka Annisa sendiri menempatkan diri sebagai sahabat perempuan dan laki-laki yang melakukan pendampingan terhadap istri, korban perkosaan, pelecehan seksual, kekerasan dalam pacaran, kekerasan dalam keluarga serta melakukan advokasi masalah kekerasan berbasis gender dengan menggunakan pendekatan HAM, perspektif korban dan keterlibatan laki-laki. Lembaga Rifka Annisa Women's Crisis Center merupakan lembaga Swadaya Masyarakat di Yogyakarta yang menyediakan pelayanan khusus bagi perempuan yang mengalami kekerasan. Lembaga Rifka Annisa WCC muncul karena keprihatinan atas kuatnya kecenderungan budaya patriarkhi yang menguatkan kedudukan laki-laki di satu sisi yang melemahkan kedudukan perempuan di sisi yang lain, akibatnya perempuan rentan mengalami kekerasan.

\section{A. Pengertian dan Jenis Kekerasan Terhadap Perempuan \\ 1. Pengertian Istilah Kekerasan}

Secara etimologis kekerasan diterjemahkan dalam bahasa Inggris dari kata "violence" yang artinya sebagai satu serangan atau invasi terhadap fisik maupun integritas mental psikologi seseorang. Sedangkan kata kekerasan dalam bahasa Indonesia umumnya dipahami hanya menyangkut serangan fisik belaka seperti yang dikemukakan oleh Eko Prasetyo \& Suparman M (1997: 7). Istilah kekerasan dalam Kamus Besar Bahasa Indonesia (1990: 456) adalah perihal yang bersifat, berciri keras, berupa paksaan, perbuatan seseorang atau kelompok orang yang menyebabkan cedera atau matinya orang lain atau menyebabkan kerusakan fisik/ barang orang lain. Kekerasan menurut Moeljatno dalam Kitab Undang-Undang Hukum Pidana pada pasal 89 yang berbunyi "membuat orang pingsan atau tidak berdaya disamakan dengan menggunakan kekerasan”. Kekerasan yang bertentangan dengan hukum merupakan kejahatan. Kekerasan "violence" menunjukkan kepada tingkah laku yang pertama-tama harus bertentangan dengan Undang-Undang, baik berupa ancaman saja, maupun sudah merupakan suatu tindakan nyata dan memiliki akibat-akibat kerusakan terhadap harta benda atau fisik atau mengakibatkan kematian pada seseorang. Kekerasan ini menunjukkan kepada tingkah laku yang berbeda-beda baik mengenai motif maupun mengenai tindakannya seperti perkosaan dan pembunuhan yang dimulai dengan kekerasan (Ramli Atmasasmita, 1992: 56).

Dapat disimpulkan bahwa kekerasan adalah suatu tindak perbuatan yang sewenangwenang dipergunakan sedemikian rupa sehingga mengakibatkan terjadi kerusakan baik fisik 
ataupun psikis terhadap seseorang atau barang orang lain. Kekerasan bisa juga mengakibatkan orang pingsan, tidak berdaya, bahkan matinya orang lain. Tindakan seperti perkosaan dan pembunuhan, kekerasan yang dilakukan dimulai dengan kekerasan.

\section{Pengertian Kekerasan Terhadap Perempuan (KTP)}

Deklarasi Penghapusan Kekerasan Terhadap Perempuan di Nairobi Afrika pada tanggal 15 sampai 26 Juli 1985 dinyatakan bahwa yang dimaksud dengan kekerasan terhadap perempuan adalah:

"Setiap tindakan berdasarkan perbedaan jenis kelamin yang berakibat kesengsaraan atau penderitaan perempuan secara fisik, seksual atau biologis, termasuk ancaman tindakan tertentu, pemaksaan atau perampasan kemerdekaan secara sewenang-wenang baik yang terjadi di depan umum atau dalam kehidupan pribadi. (Deklarasi Penghapusan Kekerasan Terhadap Perempuan, 1985: pasal 1)".

Perempuan adalah bagian yang tidak terpisahkan dari kehidupan manusia. Tetapi sepanjang hidupnya, tidak jarang menjadi objek dari tindak kekerasan yang dilakukan oleh lakilaki, dan sepanjang sejarahnya bukti-bukti kekuasaan laki-laki serta kerentanan perempuan selalu tidak dapat dihindarkan dan berdampak pada kehidupan perempuan. Di berbagai tempat di belahan bumi manapun, telah banyak bukti dilihat, dan tindak kekerasan terhadap perempuan ini telah menjadi sesuatu yang patut mendapat perhatian. Kekerasan terhadap perempuan adalah perwujudan ketimpangan historis dari hubungan-hubungan kekuasaan antara kaum laki-laki dan perempuan yang telah mengakibatkan dominasi dan diskriminasi terhadap kaum perempuan oleh kaum laki-laki dan hambatan bagi kemajuan terhadap mereka. Kekerasan terhadap perempuan merupakan salah satu mekanisme sosial penting yang menempatkan kaum perempuan dalam posisi subordinasi dihadapan kaum laki-laki.

Secara umum, akar kausa terjadi kekerasan terhadap perempuan seperti yang disebutkan Muladi, adalah budaya dominasi laki-laki (male domination culture). Dalam struktur dominasi, kekerasan seringkali digunakan laki-laki untuk memenangkan perbedaan pendapat, menyatakan rasa tidak puas, mencegah perbuatan di masa yang akan datang dan kadang kala hanya untuk menunjukan dominasi semata-mata (1997: 136). Budaya dominasi laki-laki itu tampaknya sudah diinternalisasi dengan baik oleh masyarakat atau menerima kekerasan suami terhadap istrinya. Kekerasan terhadap perempuan yang dapat dikategorikan sebagai kejahatan seksual atau gender based violence adalah kekerasan dalam keluarga atau yang sering dikenal dengan istilah 
domestic violence. Seperti juga pelecehan seksual maka dalam hukum positif, kita jumpai ketentuan yang secara eksplisit mengatur tentang kekerasan dalam keluarga. Namun demikian, beberapa pasal penganiayaan dalam KUHP dapat dijadikan landasan untuk memperkarakannya secara hukum. Dalam keseharian sering kita jumpai, dengar dan baca bahwa kejahatan ini sering terjadi apakah itu menyangkut istri, anak atau pembantu rumah tangga yang menjadi korbannya.

Menurut Eko Prasetyo dan Suparman Marzuki (1997: 38) bahwa Kekerasan Terhadap Perempuan (KTP) merupakan refleksi dari kekuasaan laki-laki atau perwujudan kerentanan perempuan di hadapan laki-laki, bahkan gambaran dari ketidakadilan terhadap perempuan. Dalam pandanganfeminis, kekerasan terhadap perempuan membuktikan adanya struktur kekuasaan yang selalu menguntungkan laki-laki. Kekuasaan yang demikian telah merajalela di segala bidang, baik dalam keluarga, pekerjaan maupun hubungan sosialnya. Perempuan dapat mengalami berbagai macam bentuk kekerasan dan kekerasan bisa terjadi di mana saja, di tempat kerja, di rumah dan bahkan di tempat umum.

Menurut Mansour Fakih (1997) bahwa Kekerasan Terhadap Perempuan (KTP) bermula pada adanya perbedaan gender yang melahirkan ketidakadilan. Perbedaan gender telah melahirkan berbagai ketidak adilan baik laki-laki dan terutama terhadap perempuan. Menurut Kamla Bhasin (1996: 16) bahwa Kekerasan Terhadap Perempuan (KTP) adalah salah satu persoalan yang pertama yang diangkat oleh gerakan perempuan Internasional untuk dibahas dan dianalisa. Kalangan sarjana feminis telah menteoritisir kekerasan ini melalui banyak cara, semuanya setuju setidaknya mengenai satu hal bahwa kekerasan itu sistematis dan melembaga. Kekerasan melembaga terhadap perempuan di banyak masyarakat. Bermacam-macam kekerasan digunakan untuk mengontrol dan menundukan perempuan. Kekerasan oleh kaum laki-laki itu bahkan dianggap absah. Kenyataan kekerasan terhadap perempuan begitu umum berlangsung dan kekerasan laki-laki sebagai suatu struktur. Kekerasan lelaki merupakan suatu struktur meskipun bentuknya tampak individual dan berbeda-beda. Kekerasan adalah perilaku yang secara rutin dialami oleh perempuan dan laki-laki. Kekerasan adalah perilaku yang secara rutin dialami oleh perempuan dan laki-laki. Kekerasan laki-laki secara sistematis dimaafkan dan diabsahkan oleh penolakan negara-negara untuk campur tangan menentangnya, kecuali dalam kasus-kasus luar biasa. 
Kekerasan Terhadap Perempuan merupakan pelanggaran HAM secara nyata yang merupakan masalah yang serius dalam negara. Menurut Prof. Dr. Saparinah Sadli yang merupakan Ketua Komisi Nasional Anti Kekerasan terhadap Perempuan mengemukakan bahwa siapa yang melakukan kekerasan seksual dan perkosaan termasuk militer tidak sekedar tindak pidana umum tapi sudah berarti melanggar HAM (Kompas, 4 Januari 2000: hal 9). Kekerasan Terhadap Perempuan menurut Rosalia Sciortino (2000: 49) adalah bentuk kekerasan yang sering diabaikan sekalipun sering terjadi yaitu kekerasan domestik yang didefinisikan sebagai penyerangan fisik atau psikologis dalam keluarga, atau lebih tepat oleh laki-laki terhadap pasangan perempuannya. Kekerasan fisik terhadap perempuan menyebabkan dan melestarikan subordinasi.

\section{B. Faktor-faktor penyebab Kekerasan Terhadap Perempuan}

\section{Faktor Intern}

Merupakan faktor dari dalam diri perempuan dan laki-laki yang melakukannya. Sesuatu yang terdapat dalam diri perempuan adalah sesuatu yang menarik, disadari ataupun tidak disadari. Tindak perkosaan ataupun pelecehan seksual bisa timbul karena sesuatu yang ada pada perempuan itu merangsang nafsu birahi orang yang akan memperkosanya, mungkin karena cara berjalannya, cara berpakaian dan hal-hal lain yang memungkinkan itu terjadi. Kejadian seperti itu bisa terjadi kapan dan di mana saja. Faktor dalam diri laki-lakinya yang tidak bisa menahan hawa nafsunya.

Kekerasan Terhadap perempuan dalam rumah tangga yang terjadi pada istri karena banyak hal misalnya sebagai berikut: istri tidak peka terhadap suami, adanya perkataan, perbuatan, kesalahpahaman dari pihak istri yang memancing amarah suami dan memukul istrinya karena kesalahan istri berdasar standar nilai suami dan masih banyak lagi. Faktor dari suami yang mudah marah, mudah tersinggung dan lain sebagainya yang memicu terjadinya kekerasan dalam rumah tangga. Faktor penyebab kekerasan terhadap perempuan yang terjadi dalam pacaran, karena pihak perempuan tidakdapat menolak keinginan pacarnya dalam hal melakukan kegiatan yang menjurus pada seks.

\section{Faktor Instern}

Menurut Muladi (1997: 136) kekerasan terhadap perempuan terjadi, karena adanya anggapan bahwa laki-laki berdominasi yang sering digunakan untuk memenangkan pendapat, 
menyatakan tidak puas, mencegah perbuatan yang akan dan kadang kala hanya untuk menunjukkan dominasi semata-mata. Budaya dominasi laki-laki nampaknya sudah diinternalisasi dengan baik oleh masyarakat, karena itu tidak aneh dalam diri mereka (perempuan) membenarkan atau menerima kekerasaan suami terhadap istrinya. Anggapan masyarakat bahwa laki-laki atau suami memiliki kedudukan lebih tinggi dari perempuan atau istrinya sekehendak hatinya.Adanya perilaku meniru seperti seorang anak yang sering melihat bapaknya melakukan kekerasan terhadap ibunya, akan berkecenderungan melakukan hal yang sama terhadap pasangannya. Dan ada pula tentang penafsiran yang keliru atas ajaran agama, misalnya "suami boleh memukul istrinya apabila nusuz". Ajaran ini sering dipahami sebagai pembenaran pemukulan terhadap istri.

Faktor ekstern lainnya yang menyebabkan terjadinya tindak KTP adalah budaya patriarkhi yang masih mengental dalam masyarakat. Pengertian patriarkhi secara harfiah berarti kekuasaan bapak atau "Patriarkhi (patriarch)". Mulanya, patriarkhi digunakan untuk menyebut suatu jenis "keluarga yang dikuasai oleh kaum laki-laki”, yaitu rumah tangga besar patriarkhi yang terdiri dari kaum perempuan, laki-laki muda, anak-anak, budak dan pelayan rumah tangga yang semuanya berada dibawah kekuasaan si laki-laki penguasa itu. Sekarang istilah itu digunakan secara lebih umum untuk menyebut sistem yang membuat perempuan tetap dikuasai melalui bermacam-macam cara (Menggugat Patriarkhi, 1996: 1). Wujud patriarkhi adalah pemukulan suami terhadap istri. Bila perempuan berontak dianggap tidak fiminis dan itu membuat perasaan dan pengalaman subordinasi merusak harga diri dan rasa percaya diri, serta membatasi aspirasi perempuan. Perempuan selalu dalam sistem dominasi dan superioritas laki-laki, menjadi sistem kontrol dimana perempuan dikuasai. Suatu sistem dari struktur dan produk-produk sosial dimana kaum laki-laki menguasai, menindas, dan mempergunakan atau menggunakan dengan sewenangwenang terhadap perempuan.

Pemahaman bahwa patriarkhi itu sistem sangat penting hal ini membantu dalam menolak pendapat penggolongan secara biologis bahwa laki-laki dan perempuan secara alamiah berbedabeda karena biologis atau badannya, dan karena itu mendapat peran yang berbeda, atau bahwa setiap laki-laki selalu berada dalam posisi subordinat. Melekat dalam sistem ini adalah ideologi yang menyatakan bahwa laki-laki lebih tinggi dari perempuan, bahwa perempuan harus dikontrol oleh laki-laki dan bahwa perempuan adalah bagian dari laki-laki. 
Dalam kebudayaan Jawa terdapat sebuah ungkapan yang sangat merendahkan kemanusiaan, yang menempatkan kaum ibu tidak lebih dari sekedar barang : "nek awan dadi teklek, nek wengi dadi lemek" (bila siang sebagai alas kaki, dan bila malam tidak lebih menjadi alas tidur sang laki-laki). Berbicara kodrat, maka sudah barang tentu hal besifat kodrati tersebut ada, yakni bahwa otonomi tubuh perempuan berbeda dengan laki-laki. Perkara kodrati inilahyang kerap kali menjadi pangkal perselisihan yang sangat penting, terutama oleh keterlibatan pemikiran keagamaan yang memang sejak awal telah keliru memahami makna kodrati tersebut, sebagai akibatnya kodrat anatomi tersebut ditafsirkan sebagai kodrat sosio-kultural. Pemahaman keliru atas kodrat tersebut melembaga dalam dongeng, kisah-kisah pelajaran-pelajaran, tetapi juga telah masuk merasuk dalam pemahaman kaum perempuan sendiri. Hal ini yang sesungguhnya menjadi faktor utama yang memperkuat kelanggengan kultur patriarkhi.

Pada mitos kecantikan yang harus melekat pada diri seorang perempuan . Mitos ini pula telah menempatkan kaum perempuan dalam posisi terekploitasi dan menjadi sasaran (target group) yang potensial bagi produk-produk industri, dari pakain sampai perhiasan. Mitos ini juga yang menjadi tanah subur bagi pelestarian nilai-nilai yang melemahkan perempuan.

\section{Akibat yang timbul dari kekerasan terhadap perempuan}

\section{Gangguan Kesehatan Jasmani}

Kekerasan yang dilakukan terhadap perempuan mengakibatkan terjadinya gangguan pada kesehatan jasmani. Korban kekerasan akan merasakan sakit pada jasmaninya ataupun organ reproduksinya.

Menurut Budi Wahyuni (1997: 58) bahwa berbagai akibat yang harus ditanggung perempuan pasca relasi seksual merupakan petunjuk bahwa suka sama suka adalah sebuah manipulasi, bukan komitmen setara. Radang vagina, perdarahan atau berbagai persoalan kesehatan yang muncul akibat penggunaan alat-alat kontrasepsi, merupakan sebagai dari dampak hubungan yang selama ini tidak terpantau memadai. Seseorang yang dilukai, diserang, dipukul dan sebagainya akan mendapati bekas atau luka akibat tindakan kekerasan itu pada tubuhnya, ada yang berlaku sementara dan ada pula yang permanen (tidak akan bisa hilang atau terus membekas sepanjang hidup). 


\section{Gangguan Kesehatan Rohani}

Kekerasan yang dilakukan terhadap perempuan mengakibatkan terjadinya gangguan kesehatan rohaninya. Seseorang yang mengalami kekerasan akan merasa trauma, kecewa, sakit hati, marah, sedih dan berakibat pada psikologisnya.Dampak psikologis masalah kekerasan merupakan persoalan yang lebih serius dibanding dampak fisik. Kekerasan mengikis harga diri dan menempatkan perempuan pada risiko yang lebih besar untuk mengalami berbagai macam masalah kesehatan mental termasuk depresi, stres pasca trauma, bunuh diri, sampai dengan penyalahgunaan alkohol dan obat-obatan.

\section{Hukum yang mengatur kejahatan seksual}

Kejahatan seksual adalah kejahatan yang berkaitan dengan pelaminan atau seksualitas dan lebih khusus lagi yang berkaitan dengan seksualitas perempuan, maka dalam kitab UndangUndang Hukum Pidana (KUHP) hanya akan kita dapati dalam bab yang mengatur tentang "Kejahatan terhadap Kesusilaan”. Dalam KUHP, kejahatan susila itu dirumuskan dalam suatu sistematik delik sebagai mana termuat dalam buku II Bab XIV tentang Kejahatan Kesusilaan yang meliputi pasal 281 sampai pasal 303 bis, dan buku III Bab VI tentang pelanggaran Kesusilaan yang meliputi pasal 532 sampai dengan 547.

Dari perumusan pasal-pasal yang termuat dalam buku II, Kejahatan terhadap Kesusilaan secara garis besar dapat dibedakan dalam:

1. Perbuatan pidana melanggar kesusilaan yakni kejahatan yang memuat dalam pasal 281 (melanggar kesusilaan di muka umum), pasal 282 dan pasal 283 (pornografi), pasal 284 (perzinahan), pasal 285 (perkosaan), pasal 289, pasal 290, pasal 293, pasal 294, pasal 295 (perbuatan cabul), pasal 292 (hubungan kelamin dengan sejenis dan belum dewasa), pasal 296 (mucikari), pasal 297 (perdagangan perempuan dan anak laki-laki belum dewasa), pasal 299 (pengguguran kandungan atau abortus).

2. Perbuatan lain yang dianggap melanggar kesopanan yakni kejahatan yang termuat dalam pasal 300 (menjual minuman memabukkan dan membuat orang mabuk), pasal 301 (menyerahkan anak untuk mengemis atau untuk melakukan pekerjaan berbahaya), pasal 302 (penganiyaan terhadap hewan), pasal 303 (perjudian)

Dalam KUHP tidak memuat penjelasan dan batasan tentang apa sebenarnya yang dimaksud dengan kesusilaan itu. Akibatnya dalam prakteknya khususnya untuk penerapan pasal 
281 KUHP (perbuatan cabul didepan umum), amat sulit dilakukan. Tambah lagi dilihat dari sistematikanya penempatan bentuk-bentuk kekerasan seksual tersebut dalam bab tentang kejahatan tehadap kesusilaan (crime against ethics) telah mengaburkan persoalan mendasar dari kejahatan seksual yakni pelanggaran terhadap integritas dan eksistensi diri manusia. Seharusnya kejahatan seksual ini lebih tepat jika diletakkan dalam bab tentang kejahatan yang membahayakan orang (crime against person) yakni dalam Bab VII KUHP.

Istilah kesusilaan menurut pengertian secara etimologis, berasal dari kata "su" dan "sila" (Sansekerta) yang berarti prinsip, dasar, a (aturan hidup) (sila) yang baik ( $s u$ ). Dengan demikian maka semua aturan hidup yang baik-baik berasal dari aturan sopan santun, moral, agama atau adat istiadat maupun yang berdasar asas kepantasan atau kepatutan, termasuk didalam pengertian kesusilaan. Dapat dikatakan bahwa hampir semua aspek yang menyangkut hubungan kita terhadap sesama manusia, lingkungan, Tuhan dan bahkan sikap kita sendiri diatur oleh norma kesusilaan (Achmad Charris Zubair, 1987: 30).

Namun demikian ternyata bahwa apa yang dianggap baik oleh seseorang atau suatu bangsa belum tentu dianggap baik oleh orang atau bangsa lain. Adalah sulit untuk menentukan baik atau buruk yang dapat dijadikan pedoman bagi setiap orang dalam bertingkah laku sehari-hari. Oleh karena hal tersebut sangat tergantung pada karakter, pandangan hidup, dan sistem nilai dari orang atau bangsa yang bersangkutan. Pada umumnya mereka kemudian menjaga dengan menuangkannya dalam ketentuan perundangan yang berlaku bagi masyarakat tersebut. Akibatnya banyak perbuatan yang sebenarnya merupakan kejahatan seksual seperti misalnya perkosaan dalam perkawinan (marital rape) tidak dikategorikan sebagai suatu kejahatan karena nilai-nilai dominan yang dianut oleh masyarakat adalah bahwa seorang istri harus selalu tunduk pada kemaun seksual suami.

Pengertian kesusilaan seperti disebut diatas tadi mendapat menyempitan arti. Pada umumnya kata kesusilaan selalu dihubungkan dengan hal-hal yang berbau seks atau perkelaminan saja. Penyebutan kata delik atau kejahatan susila maka asosiasi kita pastilah pada perbuatan-perbuatan yang berhubungan dengan pelanggaran-pelanggaran hukum dibidang seksual seperti misalnya perzinahan, pelacuran, homoseksualitas atau perbuatan lain yang "sex realed" sifatnya seperti perbuatan cabul, abortus, dan lain-lain. 


\section{E. Lembaga Swadaya Masyarakat dan Women Crisis Center}

\section{Pengertian Lembaga Swadaya Masyarakat}

Lembaga Swadaya Masyarakat Perempuan menyadari bahwa Pusat Pelayanan terhadap korban kekerasan masih sangat kurang, sehingga dibutuhkan proses pembelajaran bagi para LSM yang telah melakukan pelayanan tetapi belum mempunyai Pusat pelayanan atau Women's Crisis Center (WCC) dengan para LSM yang telah lama mempunyai WCC. Secara historis, kekerasan terhadap perempuan.Keberadaan Women,s Crisis Center di Indonesia memang telah sangat dibutuhkan.Secara historis, kekerasan terhadap perempuan telah terjadi sejak dulu. Yang sangat menyedihkan, pada era modern ini justru kekerasan terhadap perempuan bertambah marak dan kelihatannya makin meningkat dan menguat. Bahkan gerakan anti kekerasan yang rutin digulirkan para aktivitas perempuan belum dapat meredamnya.

Women's Crisis Center yang pada awalnya digagas oleh para feminis Inggris pada awal tahun 1970-an adalah untuk menyediakan tempat pengaduan bagi perempuan korban kekerasan domestik, lengkap dengan shelter atau rumah amannya. Meskipun sesungguhnya banyak dokumen. Meskipun sesungguhnya banyak dokumen mengungkapkan bahwa pada abad-abad yang lebih awal yaitu pada abad 18 telah tercatat adanya protes-protes terhadap masalah pemukulan terhadap istri, namun persoalan pemukulan terhadap istri mulai menjadi issu yang ramai dibicarakan, setelah gerakan protes feminis di Inggris yang kemudian diikuti dengan gerakan feminis di Amerika pada tahun 1970-an hingga 1980-an. Pada masa inilah kampanye politik mulai dilakukan untuk menentang masalah pemukulan terhadap istri dan gerakan ini dikenal sebagai gelombang pertama feminisme. Para aktivis perempuan di negeri ini mulai membicarakan soal perlunya layanan rumah aman (shelter/safe house/refugehause) bagi perempuan yang lari dari rumahnya untuk menyelamatkan diri dari penganiayaan pasangannya.

Dalam Women's Crisis Center (Pusat Krisis Perempuan), korban Kekerasan Terhadap Perempuan (KTP) mendapat layanan konseling, baik dengan dengan cara tatap muka (konseling langsung) maupun konseling melalui telepon (hot line) dan melalui media surat atau media lainnya. Layanan konseling dimaksudkan untuk memberikan terapi psikologis agar perempuan korban kekerasan memiliki rasa percaya diri dalam merencanakan langkah-langkah selanjutnya. Selain pelayanan konseling, pusat-pusat krisis ini juga menawarkan layanan ligitasi atau bantuan hukum, bila perempuan ingin membawa kasus kekerasan yang dialaminya ke Pengadilan. Ciri 
yang menonjol dari keberadaan pusat krisis bagi perempuan korban kekerasan ini adalah keberadaan rumah aman atau shelter yang biasa dihuni oleh korban untuk sementara waktu.

\section{Pengertian Women's Crisis Center}

Definisi WCC berbasis intitusi menurut Hartian Silawati adalah berikut:

"Sebuah organisasi yang bertujuan memberikan pendampingan pada perempuan korban kekerasan, dan juga mengupayakan perubahan kultur dan struktur masyarakat dengan membangun jaringan kerja untuk tujuan tersebut. WCC berbasis institusi memiliki bangunan kantor, bekerja dengan memakai sebuah struktur kelembagaan formal, termasuk di dalamnya punya sifat dan cara kerja WCC yang memerlukan banyak ahli dari berbagai bidang serta memerlukan kerja sama dengan berbagai pihak, membuat WCC jenis ini lebih tepat atau kebanyakan berlokasi di perkotaan(Menggagas Women's Crisis Center di Indonesia, 2001: 38).

\section{Program di dalam WCC}

Pada dasarnya kita dapat membagi program di dalam WCC kedalam dua kategori besar, yaitu:

\section{a. Pendampingan korban (bersifat pelayanan).}

1) Program pendampingan korban dapat berupa konseling, baik itu konseling kesehatan psikologis, spiritual, dan kesehatan. Konseling ini dapat dilakukan secara tatap muka, namun hendaknya juga memberikan kesempatan bagi mereka yang ingin melakukan konseling melalui telepon atau surat, karena kadang korban belum siap untuk membuka jati dirinya atau mungkin juga memang tidak punya waktu ataupun peluang untuk datang langsung berkonsultasi.

2) Selain itu sedapat mungkin korban juga dapat diberi pendampingan hukum yang bersifat litigatif. Untuk memenuhi hal ini, WCC memang idealnya mempunyai sendiri pengacara. Kalau WCC tidak dapat memberikan litigasi oleh pengacara mereka sendiri, maka harus diupayakan rujukan kepada pada pengacara yang jelas berperspektif gender.

3) Suport group adalah kelompok yang terdiri dari survivor dengan jenis kekerasan yang sama, yang dibentuk untuk memfasilitasi survivor berbagi rasa, membangun kekuatan, kepercayaan diri berdasarkan tukar pengalaman antar mereka dan juga agar survivor tidak merasa sendiri serta terjadi proses pembelajaran dan pemberdayaan antar survivor.

b. Shelter atau rumah aman, fasilitas ini dibuat untuk melengkapi layanan konseling, utamanya untuk survivor yang ada pada situasi terancam jiwanya, seperti misalnya 
diancam oleh pasangannya, dikejar-kejar pelaku, dan sebagainya. Dapat juga ada suatu kondisi yang mengharuskan korban untuk sementara waktu menyepi agar dapat mengambil keputusan yang tepat untuk dirinya.

\section{c. Advokasi}

Advokasi dapat menjadi program yang sejajar dengan program pelayanan, juga sebagai program pendukung pelayanan. Di negara-negara yang persoalan hukum kebijakan negaranya serta kesadaran masyarakat akan kekerasan tehadap perempuan sudah memadai, advokasi tidak merupakan program yang terlalu penting untuk dilakukan sendiri oleh sebuah WCC.

\section{F. Hasil Penelitian dan Pembahasan}

\section{Deskripsi tentang Lembaga Rifka Annisa}

Lembaga Rifka Annisa WCC yang berarti sahabat perempuan adalah WCC yang berdiri atas prakarsa beberapa aktivis perempuan yang bertujuan memberikan pendampingan bagi perempuan korban kekerasan. Para klien yang datang banyak memiliki masalah di luar kekerasan terhadap perempuan, namun tetap dilayani karena sebagai sosialisasi keberadaan Rifka Annisa juga berusaha membuka masalah-masalah yang muncul di sekitar kekerasan terhadap perempuan.

Lembaga Rifka Annisa WCC mempunyai tujuan yaitu: (1) Melakukan pendampingan perempuan korban kekerasan, (2) Melakukan sosialisasi dan penyadaran mengenal masalah kekerasan terhadap perempuan dan masalah gender kepada masyarakat dan (3) Melakukan langkah-langkah strategis dalam upaya perubahan kebijakan. Lembaga Rifka Annisa WCC mempunyai visi yaitu: Kekerasan terhadap perempuan di sepanjang hidupnya merupakan pelanggaran hak asasi manusia, karenanya kekerasan terhadap perempuan tidak dapat dibiarkan.Lembaga Rifka Annisa WCC mempunyai misi yaitu: melakukan pendampingan terhadap korban kekerasan terhadap istri, perkosaan, pelecehan seksual, kekerasan dalam keluarga serta melakukan advokasi masalah kekerasan berbasis gender dengan menggunakan pendekatan Ham, perspektif korban (mengutamakan kepentingan korban) dan ketertiban lakilaki. Falsafah dasar perjuangan dilandasi falsafah sesungguhnya perempuan dan laki-laki sama kedudukannya dihadapan Allah SWT, sehingga perempuan harus dibebaskan dari tindak kekerasan. 


\section{Upaya Lembaga Rifka Annisa WCC dalam memangani Korban Kekerasan terhadap Perempuan}

\section{a. Upaya Preventif}

Upaya preventif adalah upaya yang dilakukan Lembaga Rifka Annisa WCC dalam mencegah terjadinya tindakan kekerasan terhadap perempuan. Upaya tersebut dilakukan oleh Divisi Diklat, Litbang dan Humas. Upaya-upaya tersebut meliputi: (1) Diskusi-diskusi, (2) training penanganan perempuan korban kekerasan bagi TPPKK, (3) Kumpulan catatan (position paper), (4) Pengembangan konsep RPK, (5) Pandangan mengenai persepsi gender, (6) Pemantau tindakan Ligitatif yang dijalani oleh seorang korban kekerasan, (7) Program jaringan contohnya Lokakarya, (8) Penerbitan leaflet, buletin, majalah, (9) Mengelola 2 program radio dengan dua stasiun berbeda, (10) Pengelolaan perpustakan, dan (11) Program pantau.

\section{b. Upaya Represif}

Upaya represif adalah upaya yang dilakukan Lembaga Rifka Annisa WCC untuk menangani korban kekerasan terhadap perempuan. Lembaga Rifka Annisa WCC memberikan pelayanan terhadap perempuan korban kekerasan dengan dua metode penanganan sebagai berikut: (1) korban datang langsung ke Rifka Annisa, (2) korban didapatkan melalui outrech yaitu upaya mengetahui korban dengan cara perkenalan di Rifka Annisa WCC langsung kepada korban kekerasan, dilakukan untuk klien yang baru maupun lama.Upaya divisi pendampingan sebagai berikut: (1) konseling, (2) Litigasi, Mengelola shelter, (4) Pendampingan medis, (5) Home visit dan (6) Monitoring dan evaluasi.

\section{Hambatan-hambatan Lembaga Rifka Annisa WCC dalam menangani korban Kekerasan Terhadap Perempuan}

Dalam melaksanakan pendampingan terhadap korban KTP, Lembaga Rifka Annisa WCC mengalami hambatan-hambatan sebagai berikut:

a. Dari korban

1) Korban menyembunyikan informasi, berbohong tentang sesuatu hal, padahal hal tersebut penting untuk diinformasikan.

2) Korban tipe orang yang penakut dan peragu.

3) Korban suka bertahan pada opininya sendiri. 
4) Korban menuntut hak-haknya untuk ke Pengadilan sementara bukti-bukti dan saksi belum mencukupi.

b. Dana yang belum memadai dalam menunjang program kerja lembaga tersebut.

c. Sumber Daya Manusia yang belum optimal jumlahnya dalam mendampingi korban KTP.

d. Dukungan masyarakat terhadap tindakan kekerasan terhadap korban KTP yang tidak segera melapor kepada polisi bila terjadi tindakan KTP.

e. Undang-Undang yang berlaku belum cukup melindungi korban KTP.

f. Praktisi hukum yang belum sadar gender, contohnya polisi yang terkadang memojokkan korban KTP.

Untuk mengatasi hambatan-hambatan tersebut Lembaga Rifka Annisa WCC berupaya untuk:

a. Terhadap korban

1) Memberikan pengertian dan pemahaman terhadap perempuan korban kekerasan, agar mau terbuka dalam mengutarakan permasalahannya.

2) Mendidik korban untuk mandiri, meyakinkan korban, bahwa mereka dalam keadaan aman sehingga tidak perlu ragu, cemas bahkan takut.

3) Sedangkan untuk menghadirkan bukti-bukti dan saksi, Lembaga Rifka Annisa WCC berusaha menurut kemampuan, jika memang tidak ada bukti dan saksi maka tidak memaksa diri

b. Berusaha mengisi kekurangan dana dengan fund rising.

c. Mengadakan pelatihan-pelatihan dan training-training pendampingan korban KTP bagi para staf di Lembaga Rifka Annisa WCC.

d. Mengajak masyarakat untuk berpartisipasi dalam menegakkan keadilan dan kesetaraan gender.

e. Bekerjasama dengan praktisi hukum dalam penentuan kebijakan pembuat Undang-Undang.

f. Memberikan pelatihan-pelatihan dan training-traning pada praktisi hukum, contohnya kepada polisi dan pelayan kesehatan (rumah sakit) untuk ikut dalam training pendampingan korban kekerasan berwawasan gender. 


\section{Kesimpulan}

Upaya yang dilakukan Lembaga Rifka Annisa Women's Crisis Center dalam menangani perempuan korban kekerasan ada 2 upaya sebagai berikut: (1) Upaya preventif yaitu: Diskusidiskusi tentang KTP, Traning penanganan perempuan korban kekerasan bagi TP-PKK, Kumpulan Catatan (position paper), Pengembangan konsep RPK, Pandangan mengenai persepsi gender (Survey persepsi gender) pembuat kebijakan, Pemantauan tindakan ligitatif yang dijalani oleh perempuan korban kekerasan dan perumusan kebijakan praktek aparat hukum, program jaringan, penerbitan, kolom tetap di majalah Manggala dan Harian Kompas, Program radio dengan talk show "Swaranisa", Pemutaran dan diskusi film, Pengelolaan perpustakaan, Program pantau keluarga. (2) Upaya Represif yaitu: Konseling, Ligitasi, Mengelola shelter, Pendampingan medis, Home visit dan monitoring.

\section{Daftar Pustaka}

Depdikbud. (1990). Kamus Besar Bahasa Indonesia. Jakarta: Balai Pustaka.

Eko Prasetyo dan Suparman Marzuki. (1997). Perempuan dalam Wacana Perkosaan. Yogyakarta: Pustaka Pelajar.

Kamla Basin. (1996). Menggugat Patriarhi. Yogyakarta: Yayasan Bentang Budaya.

Mansour Fakih (ed). (1996). Gender dan Pembangunan. Yogyakarta: Pustaka Pelajar offset. Ramli Atmasasmita. (1992). Teori dan Kapita Selekta Kriminologi. ): Eresco.

\section{Surat Kabar}

Kompas, Selasa 4 Januari 2000, hal 9.

Kedaulatan Rakyat, Senin, 6 Januari 2003, hal 6.

Bernas, Rabu, 15 januari 2003, hal 16.

Kedaulatan Rakyat, Kamis, 13 Februari 2003, hal 6.

Kompas, Senin, 14 Juli 2003, hal 45. 